\title{
A nested case-control study of fatal work related injuries among Brazilian steel workers
}

\author{
S M Barreto, A J Swerdlow, P G Smith, C D Higgins
}

Departamento de Epidemiologia e Antropologia Medica, Centro de Pesquisa Rene Rachou, Fiocruz, Av Augusto de Lima 1715, Belo Horizonte, CEP 30.190.002, Brazil S M Barreto

\section{Epidemiological Monitoring Unit, Department of Epidemiology and Population Sciences, London School of Hygiene and Tropical Medicine, Keppel Street, London WC1E 7HT \\ A J Swerdlow \\ P G Smith \\ C D Higgins}

Correspondence to: $\operatorname{Dr} S M$ Barreto, Laboratorio de Epidemiologia, Centro de Pesquisa Rene Rachou, Av Augusto de Lima 1715, CEP 30.190.002, Belo Horizonte Brazil.

Accepted 26 February 1997
Conclusions-The study identified parts of the steelworks and types of hazard associated with greatly increased risk of fatal accident. Research and measures to prevent accidents need to concentrate on these areas and the people working in them. The use of a hazard score was successful in identifying high risk, and similar scoring might prove useful in other industrial situations.

\section{(Occup Environ Med 1997;54:599-604)} ary 1977 and August 1990, who wer followed up to November 1992. The cases were defined as all workers in the cohort who died from injury in the study period and whose death had been notified to the Brazilian Ministry of Labour as being related to work. Four controls per case, matched to cases on year of birth, were randomly selected from among workers employed in the plant at the time of death of the matching case. Data on potential risk factors for occupational injury were extracted from company records; for the controls these data were abstracted for the period preceding the death of the matching case.

Results-There were 37 deaths related to work injuries during the study period. Four surviving workers were selected as controls for each case, but for eight the personnel records were incomplete, leaving 140 controls in all. Significantly increased risk of fatal injury related to work was associated with exposure to noise, heat, dust and fumes, gases and vapours, rotating shift work, being a manual worker, and working in the steel mill, coke ovens, blast furnaces, and energy and water supply areas. Risk of fatal injury related to work increased with intensity of exposure to noise $(P$ (trend) $=0.004)$ and heat $(P<0.001)$, and increased greatly with a hazard score that combined information on noise, heat, dust, and gas exposure $(P<0.001)$. Number of years of schooling $(P=0.03)$ and salary level $(P=0.03)$ were both negatively associated with risk. In a multivariate analysis including all these significant factors, only hazard score and area of work remained associated with death from injury related to work. The highest risks were for men exposed to all four environmental hazards (odds ratio (OR) $19.4 ;$ 95\% confidence interval $(95 \%$ CI) 1.1 to 352.1 ) and those working in the energy supply area (OR 18.0; 1.6 to 198.1).
Keywords: occupation; nested case-control; injury; mortality; steelworks

In Brazil, about 640000 injuries related to work were reported to the national Health and Safety Authorities in $1991 .^{1}$ According to the Ministry of Health, $13 \%$ of the injuries in 1988-9 resulted in no loss of working days, $83 \%$ in loss of up to 15 days of work, $2 \%$ led to temporary disability, $0.4 \%$ led to permanent disability, and $0.4 \%$ were fatal.

Steelworks are hazardous in many ways. The dangers include gas explosions, pouring of molten metal or slag, movement of locomotives and wagons, furnace charges, cranes, ladles, and other loads, and falls of heavy objects. Lost time due to injuries from foreign bodies, such as blown sand, chips, dust from power tools and sparks, are common. ${ }^{2}$ Vibration, strenuous physical work, and job stress are other important potential risk factors for steel workers. In Campinas, Brazil, where there is a large occupational injuries in metal workers in 1979-89 was 34.3 per 100000 employees per year-lower than that found in construction workers (59.8) but much greater than in workers in the food industry (14.8) or retailing $(9.4){ }^{4}$

Few epidemiological studies of the mortality of workers in the iron and steel industry have reported the risk of death from injuries. ${ }^{5-8}$ In Finland, Koskela et al found an excess mortality from injuries (mainly suicide and transportation accidents) among casters, furnacemen, and fitters. There was a nonsignificant increased risk for accidents among labourers in a cohort study of steel workers in the United States. ${ }^{5}$

In a cohort analysis of workers employed at the manufacturing plant of USIMINAS, in Minas Gerais, Brazil during 1977-92 we found that mortality from unintentional injury was $50 \%$ above that of the general population (standardised mortality ratio (SMR) 150, 95\% steelworks, the crude incidence for fatal 
confidence interval ( $95 \% \mathrm{CI}) 130$ to 172$)^{9}$ The present study was conducted to establish the extent to which, and how, the excess mortality was related to work. USIMINAS kept detailed records on its workers and of potential hazards, and we have used these records to investigate reasons for the high mortality, to delineate high risk groups, and to consider where potential preventive measures need to be focused.

\section{Materials and methods}

The USIMINAS steelworks is one of the largest producers of uncoated flat steel in the Americas. It has a workforce of 12500 and covers an area of $11 \mathrm{~km}^{2}{ }^{2}$ Until 1993 it was the largest producer of coal derived benzene and other aromatic hydrocarbons in Brazil.

The study was of nested case-control design, comparing occupational, medical, and social histories of USIMINAS workers who died of injury related to work, with those of selected surviving cohort members. Cases and controls were drawn from all 21816 men employed at the USIMINAS plant at any time between 1 January 1977 and 31 August 1990.

Cases were defined as workers who died of injury related to work while employed at the USIMINAS plant during the study period. Work related injuries were taken to be those in which injury was specified as the underlying cause of death on the death certificate and the death had been notified by the plant as work related. For each case, four controls were selected at random from among all steel workers employed in the plant at the time of the case's death and with the same year of birth as the case.

Data on potential risk factors were abstracted from personnel, hygiene, and medical records relating to the period preceding the death of the case, and for the equivalent period for the controls. For this purpose an "index" date corresponding to the month and year of death of the case was designated for each matched control. Sociodemographic data obtained from personnel records included educational level at the start of employment, marital status, and salary grade at the nearest date before the index date. Records of routine examinations by doctors of the Occupational Health Department were used to obtain information on health history. Workers were generally examined at the start of employment, and subsequently every one or two years. Records were checked for psychiatric and neurological illnesses, use of psychotropic medication, physical disability such as hearing loss, and previous injury.

Occupational histories were obtained from personnel records, and included job title, work area, work category, and shift pattern at the index date. The steel plant operates for 24 hours a day, including weekends and holidays. Different groups of workers are employed on one, two, or three shift schedules. These are: three shifts $(0700-1500,1500-2300$, or 2300 0700), including weekends and bank holidays; two shifts (0700-1500 or 1500-2300), includ- ing weekends but not overnight work; and one shift (0730-1730), including a two hour lunch break, Monday to Friday.

The Occupational Health and Industrial Hygiene Departments of USIMINAS had conducted an earlier survey linking detailed descriptions of work areas, job titles, materials, and technologies used, to routine measurements taken on common occupational hazards identified in the plant. Subsequently, they developed a database with information for each worker on the level of exposure to up to 22 important health hazards during employment in the plant. For the present study, the industrial hygienists at the plant used this database and the information on job title and area of work already collected for each case and control to identify their exposure status to the main health hazards in the plant at the index date. The hygienists were unaware of the casecontrol status of the subjects. The main health hazards identified were air contaminants, heat, noise, and vibration. Air contaminants included metal and mineral dust from sintering, pelletising, and foundry operations, metal fumes from furnaces and scarfing, gases and vapours from blast furnaces, coking, welding, cleaning motors, and maintenance processes. The industrial hygienists also used their knowledge and experience to classify the intensity of exposure to noise, heat, and vibration into three levels-low, moderate and high. For instance, exposure for eight hours a day to noise levels from 85 to $89 \mathrm{~dB}(\mathrm{~A})$ Leq was classified as low, and similar exposure to $95 \mathrm{~dB}(\mathrm{~A})$ Leq and above as high. The principal heat load in the steelworks is due to radiation from the ovens and the molten metal. Men working in front of, or on top of, furnaces were regarded as highly exposed to heat. Refractory brick workers in the steelmaking plant and workers in foundry shakeout operations were classified as highly exposed to vibration.

To summarise the data for statistical analysis, and to avoid small numbers within categories, the 24 departments of the plant were grouped into eight main areas of work: administration (including research and design), hot strip mill, cold strip mill, transport, maintenance (repairs and production of tools and machinery), steel mill, coke ovens or blast furnaces, and energy or water supply. The work hazards identified by the industrial hygienists were arranged into five groups: dust and fumes, gases and vapours, noise, vibration, and heat. Information on mechanical dangers, such as presence of cranes and other heavy machines and use of safety equipment was not available on records.

Cases and controls were classified into four income groups corresponding, after adjustment for inflation, to quartiles of the 1992 range of salary grades. Medical history was grouped into two main categories: neuropsychiatric disorders or use of psychoactive medication, and physical disabilities. Histories of injuries were grouped into those which were occupational and those which were nonoccupational. 
STATISTICAL ANALYSIS

Conditional logistic regression was used to compute odds ratios (ORs) both in univariate analyses and in modelling the effects of the various risk factors with adjustment for the effect of other, potentially confounding, risk factors. The analysis was conducted with Egret computer software. ${ }^{10}$ Heterogeneity of, and trends in, ORs, and the effect of each variable in the multivariate model, were assessed by likelihood ratio tests.

\section{Results}

During the study period 192 deaths occurred from unintentional injury and 37 of these were classified as work related. Eleven were caused by burns, 10 by motor vehicle accidents (eight to pedestrians and two to vehicle occupants), nine by collision with machinery, four by intoxication with gas, two by electrocution, and one by a fall from a wagon. Unfortunately, details of the events immediately surrounding these deaths were not available. Four controls were selected for each case, but personnel records were incomplete for eight controls and therefore only 140 controls were included in the analyses.

Table 1 shows the distribution of cases and controls in different categories of the various risk factors examined, together with estimates of the ORs. Men with less than five years of education had a similar risk of injury related to work to those with five to eight years of education, but each of these groups had four times the risk of men with nine or more years of education (the formal test for trend was significant because of this dichotomy of risk). Salary level was significantly negatively associated with the risk of death from injury related to work before adjustment for education (table $1: \mathrm{P}=0.03$ ), but not after this adjustment $\left(\chi_{1}^{2}\right.$ trend $=0.7$, $\mathrm{P}=0.40$ ).

There was no significant relation between fatal work related injuries and marital status, neuropsychiatric disorders, or history of physical disability (table 1). History of a previous injury related to work was associated with a more than threefold increased risk, although the association was not significant. The OR for history of previous non-occupational injury was greater than unity, but again was not significant.

Manual workers were at four times greater risk than non-manual workers (table 2), but the difference stopped being significant after adjustment for level of education (OR 3.08; 95\% CI 0.82 to 11.54). Compared with workers in the production process, the risk of fatal injury was greater for maintenance workers and lower for those employed in other jobs, but these differences were not significant (table 2). Most cases $(92 \%)$ and controls $(74 \%)$ worked on a two or three shift schedule, with most employed in the three shift schedule that included night shifts. There was a significant trend of increasing risk with increasing number of shifts (table 2: $\mathrm{P}=0.03$ ) which was not significant after adjustment for education $\left(\chi_{1}^{2}\right.$ trend $=1.7$, $P=0.19)$.
Table 1 Risk of fatal work related injury in relation to sociodemographic factors and medical history

\begin{tabular}{|c|c|c|c|}
\hline Risk factors & Cases & Controls & OR $(95 \% C I)$ \\
\hline \multicolumn{4}{|l|}{ Education (y): } \\
\hline$\leqslant 4$ & 17 & 51 & 1.00 \\
\hline $5-8$ & 16 & 46 & $0.99(0.43$ to 2.31$)$ \\
\hline$\geqslant 9$ & 4 & 43 & $0.25(0.08$ to 0.84$)$ \\
\hline$\chi_{1}^{2}$ trend & & & 4.6 \\
\hline$\widetilde{P}$ value & & & 0.03 \\
\hline \multicolumn{4}{|l|}{ Salary group ${ }^{\star}$ : } \\
\hline Low & 8 & 11 & 1.00 \\
\hline Lower middle & 20 & 78 & $0.22(0.05$ to 0.92$)$ \\
\hline Middle & 7 & 39 & $0.13(0.02$ to 0.69$)$ \\
\hline High & 2 & 9 & $0.14(0.02$ to 1.28$)$ \\
\hline$\chi_{1}^{2}$ trend & & & 4.5 \\
\hline P value & & & 0.03 \\
\hline \multicolumn{4}{|l|}{ Marital status: } \\
\hline Married & 26 & 97 & 1.00 \\
\hline Non-married & 11 & 43 & $0.86(0.31$ to 2.36$)$ \\
\hline \multicolumn{4}{|l|}{$\begin{array}{l}\text { Neuropsychiatric } \\
\text { disorder: }\end{array}$} \\
\hline No & 34 & 132 & 1.00 \\
\hline Yes & 3 & 8 & $1.57(0.28$ to 6.48$)$ \\
\hline \multicolumn{4}{|l|}{ Physical disability: } \\
\hline No & 33 & 125 & 1.00 \\
\hline Yes & 4 & 15 & $1.08(0.32$ to 3.61$)$ \\
\hline \multicolumn{4}{|l|}{ History of work } \\
\hline related injury: & & & 1.00 \\
\hline $\begin{array}{l}\text { No } \\
\text { Yes }\end{array}$ & $\begin{array}{l}34 \\
3\end{array}$ & $\begin{array}{l}137 \\
3\end{array}$ & $\begin{array}{l}1.00 \\
3.81(0.77 \text { to } 18.95)\end{array}$ \\
\hline \multirow{2}{*}{\multicolumn{4}{|c|}{$\begin{array}{l}\text { History of other } \\
\text { injury: }\end{array}$}} \\
\hline & & & \\
\hline No & 33 & 130 & 1.00 \\
\hline Yes & 4 & 10 & $1.59(0.47$ to 5.39$)$ \\
\hline
\end{tabular}

^ Information missing for 3 controls.

There were substantially increased risks of death for workers employed in certain areas of the steelworks. The areas of highest risk were coke ovens and blast furnaces, energy and water supply plants, and steel mills (table 2). Sixty seven per cent of the cases worked in these three areas. Compared with workers employed in the administration, design, and research departments, those employed in the maintenance, transport, and hot and cold strip mills also had increased risks, but not significantly so. Table 3 shows that burning and dangerous machines caused most of the deaths in the steel mill, coke ovens, or blast furnaces and energy supply areas.

Cases differed significantly from controls in their exposure to several work hazards (table 4). Noise exposure was the most common hazard in the steelworks, affecting $89 \%$ of the cases and $64 \%$ of the controls. There was a significant trend of increasing risk with increasing exposure to noise, although risk was greater for moderate than for high exposure. Exposure to heat was also a strong predictor of death from injury related to work (table 4 ), with a highly significant trend.

Smaller numbers of workers were exposed to vibration, but there was also a significant trend in risk with intensity of exposure (table 4, $\mathrm{P}=0.03$ ). The trend remained but was not significant after adjustment for education. Relative risks were also increased, and highly significant, for workers exposed to dust or fumes and gases or vapours.

We assessed the possible interaction of the occupational risk factors already discussed with duration of employment $(<2$ y $v \geqslant 2 \mathrm{y})$, age $(<30$ y $v \geqslant 30 \mathrm{y})$, and period of death (before $1987 v 1987$ onward), but in each instance the interaction term was not significant. 
Table 2 Risk of death from work related injury in relation to type of job, work schedule, and work area

\begin{tabular}{|c|c|c|c|}
\hline Risk factor & Cases & Controls & OR $(95 \% C I)$ \\
\hline \multicolumn{4}{|l|}{ Job category: } \\
\hline Non-manual & 4 & 49 & 1.00 \\
\hline Manual & 33 & 91 & $4.38(1.46$ to 13.11$)$ \\
\hline \multicolumn{4}{|l|}{ Type of work: } \\
\hline Production process & 26 & 98 & 1.00 \\
\hline Maintenance & 9 & 20 & $1.89(0.70$ to 5.06$)$ \\
\hline Other & 2 & 22 & $0.33(0.07$ to 1.56$)$ \\
\hline$\chi_{2}^{2}$ heterogeneity & & & 4.8 \\
\hline$P$ value & & & 0.09 \\
\hline \multicolumn{4}{|l|}{ Work schedule: } \\
\hline 1 shift & 3 & 33 & 1.00 \\
\hline 2 shifts & 6 & 25 & $2.41(0.51$ to 11.36$)$ \\
\hline 3 shifts & 28 & 82 & $3.30(0.97$ to 11.20$)$ \\
\hline$\chi_{1}^{2}$ trend & & & 4.6 \\
\hline$P$ value & & & 0.03 \\
\hline \multicolumn{4}{|l|}{ Work area: } \\
\hline Administration, design and research & 2 & 45 & 1.00 \\
\hline Transport & 1 & 9 & $2.40 \quad(0.20$ to 30.30$)$ \\
\hline Cold strip mill & 1 & 14 & $1.54(0.12$ to 18.86$)$ \\
\hline Hot strip mill & 3 & 20 & $2.16 \quad(0.28$ to 16.70$)$ \\
\hline Maintenance & 5 & 24 & $4.86 \quad(0.84$ to 28.24$)$ \\
\hline Steel mill & 11 & 16 & 11.36 (2.28 to 56.65$)$ \\
\hline Coke oven/blast furnaces & 10 & 8 & 25.05 (4.45 to 141.1$)$ \\
\hline Energy and water supply & 4 & 4 & 25.50 (2.50 to 260.4$)$ \\
\hline$\chi_{7}^{2}$ heterogeneity & & & 31.9 \\
\hline P value & & & $<0.001$ \\
\hline
\end{tabular}

Table 3 Distribution of deaths from injury according to underlying cause on death certificate and area of work

\begin{tabular}{|c|c|c|c|c|c|c|}
\hline \multirow[b]{2}{*}{ Cause of death } & \multirow[b]{2}{*}{ Total } & \multicolumn{5}{|c|}{ Area of work } \\
\hline & & $\begin{array}{l}\text { Administration/ } \\
\text { design/research }\end{array}$ & $\begin{array}{l}\text { Steel } \\
\text { mill }\end{array}$ & $\begin{array}{l}\text { Coke oven } \\
\text { and blast } \\
\text { furnace }\end{array}$ & $\begin{array}{l}\text { Energy } \\
\text { and water } \\
\text { supply }\end{array}$ & Others \\
\hline Motor vehicle injury & 9 & 1 & 2 & 0 & 2 & 4 \\
\hline Fall & 1 & 0 & 0 & 0 & 0 & 1 \\
\hline Burning & 11 & 0 & 5 & 3 & 2 & 1 \\
\hline Injury caused by machine (not & 5 & 1 & 1 & 3 & 0 & 0 \\
\hline Electrocution & 2 & 0 & 0 & $\begin{array}{l}3 \\
0\end{array}$ & 0 & 2 \\
\hline Poisoning by gases or vapours & 4 & 0 & 1 & 2 & 0 & 1 \\
\hline $\begin{array}{l}\text { Other injuries and those with } \\
\text { means not specified }\end{array}$ & 5 & 0 & 2 & 2 & 0 & 1 \\
\hline Total & 37 & 2 & 11 & 10 & 4 & 10 \\
\hline
\end{tabular}

We also developed a hazard score, counting one point for exposure to each of dust, gases, noise, and heat. Thus the lowest score was 0 , for exposure to none of these hazards, and the highest was 4, for exposure to all of them. Exposures to low levels of noise or heat were counted with zero exposure in the calculation of the score. Vibration was not included in the score as its association with risk of death was not strong, and was slight after adjustment for any of the other factors. There was a steep, highly significant $(\mathrm{P}<0.001)$ upward trend in the OR with increasing hazard score (table 4). The risk was particularly high for workers with the highest score level (OR 44.9, 95\% CI 4.4 to 459.7). Adjustment for level of education had little effect.

We examined the effect of all significant risk factors in a multivariate model. As some of the risk factors identified in the initial analysis were highly correlated, to avoid multicollinearity or several non-significant variables with large standard errors due to over adjustment, only those factors that best represented the exposure of interest were kept in the model. ${ }^{11} 12$ The factors included in the multivariate analysis were job category, shift work, work area, hazard score, and education. The work areas hot and cold strip mills, transport, and maintenance were combined in the category "other" because there was no evidence of a difference in risk between these areas (table 2).

When all of the factors were adjusted for each other, the only ones that remained statistically associated with death from injury related to work were the hazard score and area of work. The ORs for hazard score were reduced, but still large and highly significant, after adjustment for work area (table 5). There were large reductions in the ORs for working in the steel mill and coke oven or blast furnace areas after taking into account the hazard score (table 5), but the high risk for those employed in the energy and water supply areas was not greatly changed (OR 18.0). Among the four cases employed in the energy and water area, two died of burns and two from motor vehicle injury.

\section{Discussion}

We found a large, significant risk of fatal injury related to work in relation to certain work areas, and to certain environmental hazards, especially in combination. The findings are unlikely to be due to bias as the occupational histories were from dated records compiled before the occurrence of the fatal outcomes, and were abstracted without knowledge of whether individual people were cases or controls. Information on work hazards was provided by industrial hygienists also unaware of whether the study subjects were cases or controls. We think that misclassification of the type and levels of work hazards to which the steel workers were exposed at the index date is unlikely to be substantial, but if it did occur it should have affected cases and controls similarly and would thus have tended to reduce the risk estimates.

In the univariate analyses the risk of fatal injury related to work was significantly related to educational level, income, job category, shift pattern, and work area (tables 1 and 2). Education, salary level, and job category were highly correlated. In so far as education determines to a large extent, the type of employment, it is arguable whether or not adjustment for educational level is appropriate when assessing occupational factors. The main effects of occupational hazards were strongly present even after this adjustment. Working on a rotating shift pattern-that is, two or three shifts-could plausibly be a cause of accidents, ${ }^{13-15}$ but the risk for this factor was not significant when adjusted for other occupational factors.

The lack of association between physical disabilities and work related injuries might be explained by selection on health grounds. Workers with such afflictions might either not be admitted to work in, or be moved from, areas and jobs in which these disabilities would increase risk. We have no information on whether workers with a neuropsychiatric history were also removed from hazardous areas because of safety concerns. This might explain the lack of a significantly increased risk of death associated with this factor (table 1). 
Table 4 Risk of fatal work related injury in relation to exposure to selected occupational hazards

\begin{tabular}{|c|c|c|c|c|}
\hline Occupational hazard & Cases & Controls & $O R(95 \% C I)$ & Adjusted $O R^{\star}(95 \% \mathrm{CI})$ \\
\hline \multicolumn{5}{|l|}{ Noise: } \\
\hline No & 4 & 50 & 1.00 & 1.00 \\
\hline Low & 7 & 32 & $2.62(0.73$ to 9.36$)$ & $2.19(0.60$ to 8.04$)$ \\
\hline Moderate & 16 & 27 & 7.83 (2.34 to 26.36 ) & $5.72(1.63$ to 20.1$)$ \\
\hline High & 10 & 31 & $4.23(1.19$ to 15.32$)$ & $3.05(0.80$ to 11.7$)$ \\
\hline$\chi_{1}^{2}$ trend & & & 8.4 & 4.3 \\
\hline P value & & & 0.004 & 0.04 \\
\hline \multicolumn{5}{|l|}{ Heat: } \\
\hline No & 18 & 111 & 1.00 & 1.00 \\
\hline Low & 1 & 10 & $0.56(0.07$ to 4.79$)$ & $0.45(0.05$ to 4.12$)$ \\
\hline Moderate & 8 & 12 & 3.99 (1.36 to 11.69$)$ & $2.89(0.92$ to 9.07$)$ \\
\hline High & 10 & 7 & 8.29 (2.64 to 26.02$)$ & 6.80 (2.13 to 21.65$)$ \\
\hline$\chi_{1}^{2}$ trend & & & 17.4 & 12.2 \\
\hline$\widetilde{\mathbf{P}}$ value & & & $<0.001$ & $<0.001$ \\
\hline \multicolumn{5}{|l|}{ Vibration: } \\
\hline No & 29 & 125 & 1.00 & 1.00 \\
\hline Low & 3 & 11 & $1.22(0.30$ to 4.88$)$ & $1.01(0.25$ to 5.29$)$ \\
\hline Moderate & 1 & 1 & $3.59(0.27$ to 58.31$)$ & $2.58(0.15$ to 49.8$)$ \\
\hline High & 4 & 3 & 5.20 (1.16 to 23.38$)$ & $4.01(0.81$ to 19.76$)$ \\
\hline$\chi_{1}^{2}$ trend & & & 4.9 & 3.0 \\
\hline $\mathbf{P}$ value & & & 0.03 & 0.08 \\
\hline \multicolumn{5}{|l|}{ Dust or fumes: } \\
\hline No & 18 & 117 & 1.00 & 1.00 \\
\hline Yes & 19 & 23 & 4.63 (2.15 to 9.97$)$ & $4.17(1.87$ to 9.31$)$ \\
\hline \multicolumn{5}{|l|}{ Gases or vapours: } \\
\hline No & 24 & 124 & 1.00 & 1.00 \\
\hline Yes & 13 & 16 & 4.69 (1.88 to 11.69$)$ & 3.85 (1.49 to 9.94$)$ \\
\hline \multicolumn{5}{|l|}{ Any of the above } \\
\hline hazards: & & & & \\
\hline No & 3 & 45 & 1.00 & 1.00 \\
\hline Yes & 34 & 95 & 5.21 (1.53 to 17.75$)$ & $3.90(1.11$ to 13.74$)$ \\
\hline \multicolumn{5}{|l|}{ Hazard scoret: } \\
\hline 0 & 5 & 62 & 1.00 & 1.00 \\
\hline 1 & 8 & 48 & $2.20(0.67$ to 7.18$)$ & $2.12(0.63$ to 7.10$)$ \\
\hline 2 & 9 & 23 & $4.42(1.34$ to 14.60$)$ & $3.86(1.05$ to 14.25$)$ \\
\hline 3 & 8 & 6 & 16.13 (4.01 to 64.82$)$ & 14.63 (4.27 to 65.49$)$ \\
\hline 4 & 7 & 1 & 44.92 (4.39 to 459.7$)$ & 44.77 (4.05 to 494.4$)$ \\
\hline$\chi_{1}^{2}$ trend & & & 30.6 & 23.7 \\
\hline $\mathrm{P}$ value & & & $<0.001$ & $<0.001$ \\
\hline
\end{tabular}

* $O R$ adjusted for levels of education.

t Based on the number of hazards in the workplace (see text).

Table 5 Multivariate analysis of risk factors for death from work related injuries

\begin{tabular}{|c|c|c|c|c|}
\hline Risk factor & Cases & Controls & Adjust & ed $O R^{*}(95 \% C I)$ \\
\hline \multicolumn{5}{|l|}{ Hazard score: } \\
\hline 0 & 5 & 62 & 1.00 & \\
\hline 1 & 8 & 48 & 1.49 & (0.34 to 6.43$)$ \\
\hline 2 & 9 & 23 & 2.53 & $(0.56$ to 11.4$)$ \\
\hline 3 & 8 & 6 & 8.46 & (1.17 to 61.15$)$ \\
\hline 4 & 7 & 1 & 19.44 & (1.07 to 352.1$)$ \\
\hline \multicolumn{3}{|l|}{$\chi_{1}^{2}$ trend } & 9.3 & \\
\hline P value & & & 0.002 & \\
\hline \multicolumn{5}{|l|}{ Work area: } \\
\hline Administration, design and research & 2 & 45 & 1.00 & \\
\hline Steel mill & 11 & 16 & 2.42 & (0.32 to 18.28$)$ \\
\hline Coke oven or blast furnaces & 10 & 8 & 5.12 & (0.69 to 37.80$)$ \\
\hline Energy and water supply & 4 & 4 & 18.00 & (1.63 to 198.1 ) \\
\hline Others & 10 & 67 & 1.50 & $(0.24$ to 9.22$)$ \\
\hline \multicolumn{3}{|l|}{$\chi_{4}{ }^{2}$ heterogeneity } & \multicolumn{2}{|c|}{9.4} \\
\hline \multicolumn{3}{|l|}{$\mathrm{P}$ value } & \multicolumn{2}{|l|}{0.053} \\
\hline
\end{tabular}

* OR adjusted for the effects of the other factor in the table, and education, job category, and work schedule.

Although steelworks have long been regarded as hazardous places to work, ${ }^{3516}$ little published information is available from analytical epidemiological studies on injuries related to work areas and occupational hazards. There are no published mortality data with which to compare the high relative risks for fatal occupational injury found in this study for workers in the energy, coke oven, blast furnace, and steel mill areas. In a study of the Mexican steelworks of SICARTSA, ${ }^{16}$ in 1985, the unadjusted risk for disabling injury was highest for men employed in the blast furnace area, followed by the coke ovens, steel mill, and energy areas, respectively.
The high risks we found among workers employed in the steel mill, coke oven, and blast furnace areas were partly related to exposures measured in the hazard score, but not entirely so (table 5). Other known dangers of these areas are movement of locomotives, cranes, and furnace charges, falls of heavy and dangerous objects, humidity and wet floors, electrical shocks, fatigue, reduced visibility, and machine paced work.

The risk for those employed in the energy and water supply area remained high after adjustment for the hazard score. This area is vital to the steel plant. It produces, stores, and distributes to other areas vapour and pressurised air, and controls and distributes oxygen, electricity, water, fuel, and the gas generated in the coke oven and blast furnace areas. Hot objects, toxic gases, vapours and solvents, work on moving equipment, wet floors, and ladders are among the most common hazards in the area. People working in the oxygen plant are exposed to the highest noise levels in the steelworks.

Large relative risks of fatal injury were found in relation to noise, heat, dust and fumes, and to gas and vapour, especially in combination. Workers exposed to these hazards might also be exposed, however, to other factors that increase the risk of injury and which were not measured in the present study, such as intense traffic, mechanical hazards, workplace disarray, poor maintenance of equipment, and lack of protective equipment. ${ }^{17} 18$ The association between the hazard score and risk is strong, even after adjustment for the effect of work area, and it therefore seems unlikely that these other factors could completely explain this association.

There are several mechanisms by which exposure to heat, noise, gases, and dust might raise the risk of fatal accidents. As a consequence of prolonged exposure to excessive heat, steel workers have a particularly high risk of heat exhaustion and heat cramp due to loss of body fluids and salts or imbalance in body salts. If workers dehydrate beyond $1.5 \%$ of their total body weight, their physical and mental fitness deteriorate, and they become more susceptible to acute heat illnesses and accidents. ${ }^{19}$ Burns may occur in many areas: for instance, in front of furnaces, from the falling of molten metal out of ladles, and in the pouring of ingots. Risks of explosion have increased owing to the use of oxygen in modern steel making plants. ${ }^{3}$

Exposure to high noise levels is common in a steelworks (table 4). Audiometric examinations and protective equipment are usually used to minimise or retard the deleterious effects of noise on workers' hearing. Psychological distress, irritability, and increased risk of accidents have been associated with persistent exposure to intense noise. ${ }^{20} 21$ Increased risk of injuries has also been associated with exposure to intense noise in Mexican steel workers. ${ }^{16}$ Noise greater than $82 \mathrm{~dB}$ and hearing loss were estimated to account for $43 \%$ of the injuries at work among men in a Dutch shipyard. ${ }^{22}$ 
Steel workers are exposed to a range of gases, vapours, dust, and fumes, probably not equalled in any other industrial setting. ${ }^{2}$ Significant exposure to carbon monoxide can occur on top of blast furnaces or from the many pipelines inside the plant. Exposure to aromatic hydrocarbons (toluene, xylene, benzene), which are coal byproducts, can cause vertigo, feelings of drunkenness, poor memory, and sleep disorder, and has been associated with falls among painting workers. ${ }^{23-25}$ Men in some operations are exposed to heavy clouds of dust and fumes causing reduced visibility. Exposures to blown sand, coal and iron dusts, and fumes from welding are common to several operations and are associated with a high incidence of conjunctivitis and foreign bodies in the eye among steel workers. Injuries to the eye accounted for $28 \%$ of more than 17000 accidents related to work that occurred in 1976-92 at the USIMINAS plant; $95 \%$ of these eye injuries were due to foreign bodies.

Human error might also have played an important part in the cause of injury. However, human error might not have had a fatal course if environmental risks were small. The associations found for the hazard score and area of work do not undermine the possible importance of human error, but rather stress the essential contribution of hazards inherent to job and workplace.

In conclusion, this study found high risks of fatal accident in relation to certain work areas and hazards in the steel workers: $70 \%$ of the fatal work related injuries occurred in the $35 \%$ of workers employed in the coke ovens or blast furnaces, energy and water supply plants, steelmills, and areas with hazard scores of three or more. It is possible that the risk factors found in this study were, to some extent, proxies for equipment related factors (inadequate design, poor maintenance, and safeguard) and organisational factors (safety systems, training, and working procedures). Further investigation is needed to elucidate better the specific dangers in these areas of the works, and ways in which they can be made safer. Similar hazard scoring systems could be used at other steelworks, and perhaps at other heavy industrial plants, to identify high risk areas on which to concentrate preventive measures.

The study was only possible because of the full and willing cooperation of the Occupational Health Department of USIMINAS in Brazil, especially Dr Adseu Andrade, and the help of many others from the Personnel and the Industria Hygiene Departments. José Ronaldo de Almeida and Carlo AMP Filho coordinated the data collection. We are grateful to
Drs Laura Rodrigues, David Leon, Tony Fletcher, and Michael Hills for advice and to Evelyn Middleton for secretarial help. The International Agency for Research on Cancer (IARC WHO) provided financial and scientific support in the initial stage of the study and the International Development Research Centre (IDRC) funded the main study. The study formed par of SMB's PhD thesis (University of London, 1995) supported by the Brazilian Research Council (CNPQ). The Epidemiological Monitoring Unit is supported by a grant from the Medica Research Council.

1 Alves S, Luchesi G. Acidentes de trabalho e doencas profissionais no Brasil - a precariedade das informações. Informe epidemiologico do SUS 1992;3:7-19.

2 Burgess WA. Recognition of health hazards in industry. $A$ review of materials and processes. New York: John Wiley, $1980 ; 194-205$

3 International Labour Office. Encyclopaedia of occupational health and safety. Geneva: ILO, 1980:1156-61.

4 Lucca SR, Mendes R. Epidemiologia dos acidentes do trabalho fatais em uma area metropolitana da regiao sudeste do Brasil, 1979-89. Rev Saude Publ 1993;27:168-76.

5 Lloyd JW, Lundin FE, Redmond CK, Geiser PB. Long-term mortality study of steelworkers: mortality by work area. $\mathcal{f}$ Occup Med 1970;12:151-8.

6 Decoufle $P$, Wood D. Mortality patterns among workers in a grey iron foundry. Am $\mathcal{F}$ Epidemiol 1979;109:667-75.

7 Koskela RS, Hernberb S, Karava R, Jarvinen E, Nurminen M. A mortality study of foundry workers. Scand $\mathcal{F}$ Work Environ Health 1976;2:73-89.

8 Egan-Baum E, Miller BA, Waxweiler RJ. Lung cancer and other mortality patterns among foundry men. Scand $\mathcal{F}$ Work Environ Health 1981;7:147-55.

9 Barreto SM, Swerdlow AJ, Smith PG, Higgins C, Andrade A. Mortality from injuries and other causes in a cohort of 21800 Brazilian steelworkers. Occup Environ Med 1996; 53:343-50.

10 SERC. Egret reference manual. Seattle: Statistics and Epidemiology Research Corporation, 1990.

11 Greenland S. Modelling and variable selection in epidemiologic analysis. Am $\mathcal{f}$ Public Health 1989;79:340-9.

12 Armitage P, Berry G. Statistical methods in medical research. Oxford: Blackwell, 1987.

13 Fisher FM, Lieber RR, Brown FM. Trabalho em turnos e as relacoes com a saúde-doenca. In: Mendes R. Patologia do Trabalho. Rio de Janeiro: Editora Atheneu, 1995.

14 Lavie P, Kremerman S, Wiel M. Sleep disorders and safety at work in industry workers. Accid Anal Prev 1982;14 3111-4.

15 Smith L, Folkard S, Poole CJM. Increased injuries on night shift. Lancet 1994;344:1137-9.

16 Laurell AC, Nogueira M. Trabajo y salud en SICARTSA. Mexico: Programa de difusion cultural del SITUAM, 1987.

17 Joint International Labour Organisation/World Health Organisation Commitee on Occupational Health. Epidemiology of work-related diseases and accidents: 10th report of the joint ILO/WHO Committee on Occupational Health. Geneva WHO, 1989;7-71. (WHO Technical Report Series No777.)

18 Saari J. Characteristics of tasks associated with the occurrence of accidents. Fournal of Occupational Accidents $1976 ; 1: 273-9$.

19 Dukes-Dobos FN. Hazards of heat exposure. Scand 7 Work Environ Health 1981;7:73-83.

20 Kjellberg A. Subjective, behavioral and psychophysiological effects of noise. Scand $\mathcal{f}$ Work Environ Health 1990;16:29 38 .

21 Melamed S, Rabinowits S, Green MS. Noise exposure, noise annoyance, use of hearing protection devices and distress among blue-collar workers. Scand $\mathcal{f}$ Work Environ Health 1994;20:294-300.

22 Moll van Charante AW, Mulder PGH. Perceptual acuity and the risk of industrial accidents. $A m, \mathcal{F}$ Epidemio 1990;131:652-63.

23 Seppalainen AM. Neurophysiological findings among workers exposed to organic solvents. Scand $\mathcal{f}$ Work Environ ers exposed to organic solve
Health 1981; 7(suppl 4):29-33.

24 Lindstrom $K$. Behavioral changes after long-term exposure to organic solvents and their mixtures. Scand $\mathcal{F}$ Work Environ Health. 1981;16:205-12.

25 Suruda AJ. Work-related deaths in construction painting Scand $f$ Work Environ Health 1992;18:30-3. 